\author{
Г.В. Пєвцов ${ }^{1}$, О.А. Усачова ${ }^{1}$, П. Пацек ${ }^{2}$, А.О. Романюк ${ }^{1}$ \\ ${ }^{1}$ Харківський національний університет Повітряних Сил ім. І. Кожедуба, Харків \\ ${ }^{2}$ Академія військового мистецтва, Варшава, Польщза
}

\title{
КОМБІНОВАНА МЕТОДИКА ОЦІНЮВАННЯ КОМПЕТЕНТНОСТІ ЕКСПЕРТІВ ПРИ ВИБОРІ СЦЕНАРІЮ ОРГАНІЗАЦІЇ ІНФОРМАЦІЙНО-ПСИХОЛОГІЧНОГО ВПЛИВУ
}

\begin{abstract}
Запропонована методика оцінювання компетентності експертів при виборі раціонального сценарію прийняття рімення на організаиію інформаційно-психологічного впливу (ІПВ). Подана в загальному вигляді модель вибору сиенарію прийняття рішення на організацію ІПВ, яка включає в себе елементи різних методів, в тому числі методу аналізу ієрархій. Оптимізація групового рішення здійснюється на основі обтрунтованої процедури узгодження. Особливістю моделі є те, що вона враховує показник пріоритету експерта в групі, який характеризує його компетентність (важливість) в галузі інформаційно-психологічної боротьби. Окрім того, для оиінювання компетентності експертів, щьо здійснюють вибір сиенарію, враховані нестандартні характеристики, такі як творче мислення, багатоваріантність рімень, гнучкість, здібність до абстрактного мислення, креативність. Введення показника компетентності експерта дозволяє суттєво спростити методику обробки даних групової експертизи та зробити результати ї̈ застосування більш достовірними. Також запропоновано алгоритм розрахунку мінімальної чисельності експертів для проведення експертизи об'єктів впливу.
\end{abstract}

Ключові слова: групова експертиза, інформаційно-психологічний вплив, компетентність, прийняття рішення, творче мислення.

\section{Вступ}

Постановка проблеми. В умовах гібридних війн, що відбуваються по всьому світу, важливе місце займає проведення інформаційно-психологічних операцій (IПсО) як основної з форм інформаційнопсихологічної боротьби (ІПБ). Вони стають обов'язковими компонентами бойових дій (БД) i дозволяють суттєво підвищити ефективність застосування військ (сил) [1-6].

У зв'язку з цим готовність командирів, штабів кваліфіковано організовувати ІПВ на противника, тобто обирати найбільш ефективні сценарії IПВ, $\epsilon$ необхідною умовою успішного рішення з'єднаннями та частинами поставлених завдань сучасного бою. Під сценарієм ІПВ будемо розуміти вербальний опис управлінської діяльності посадових осіб органів військового управління щодо організації ІПВ на противника для досягнення поставленої мети. Наявність сценаріїв ІПВ дозволяє органам військового управління прогнозувати, при яких умовах можуть виникнути сприятлива и несприятлива ситуації в інформаційно-психологічній сфері у військах та населення в ході ведення військових (бойових) дій, планувати заходи моральнопсихологічного забезпечення військ (сил), впливи на противника, підпорядкований особовий склад та населення.
Останнім часом інтенсивно розвиваються методи експертного оцінювання ситуацій для наукового обгрунтування раціональних рішень посадових осіб органів військового управління, зокрема при проведенні IПсО [7-8]. Останнє пов'язано з тим, що використання засобів ІПВ - відносно нова сфера діяльності, в якій триває процес накопичення та осмислення різних підходів, методів та методик вирішення завдань, що виникають. Серед великої кількості експертних процедур для вирішення таких завдань однією з найбільш розповсюджених є групова експертиза, яка дозволяє забезпечити високу точність та об'єктивність кінцевих результатів. Однак отримання відповідних результатів залежить від компетентності експертів, що обумовлює особливі вимоги до складу експертних груп.

Проблема підбору експертів для проведення експертизи та визначення кращого сценарію IПВ $€$ однією 3 найбільш складних в теорії та практиці експертних досліджень. Недостатній рівень компетентності експертів при виборі сценарію ІПВ може привести до появи помилок експертизи та в подальшому до великих економічних, політичних, військових втрат.

Аналіз останніх досліджень і публікацій. Проблема оцінювання компетентності експертів, що приймають участь у груповій експертизі, в спеціалізованій літературі розглянута достатньо давно та 
широко [7-14]. Розрізняють декілька методів оцінювання компетентності експертів:

- евристичний;

- статистичний;

- тестовий;

- документальний;

- комбінований.

Евристичний метод оцінювання базується на оцінці оточення експерта або на самооцінці. Існують наступні види евристичних оцінок: самооцінка, взаємооцінка, оцінка робочою групою. Самооцінка - це метод, при якому оцінку власної компетентності дає сам експерт. Встановлено, що достовірність середньої експертної оцінки тим вища, чим більше середнє значення самооцінки членів експертної групи. Між тим результати самооцінки майже завжди суб'єктивні, що є недоліком цього методу.

Суть методу взаємооцінки полягає в тому, що кожен член експертної групи дає оцінку усім іншим експертам, а потім розраховується середня оцінка кожного експерта. Недоліками взаємооцінки $є$ наступні фактори: експерти можуть недостатньо знати один іншого; на результати оцінки можуть впливати взаємні симпатії або антипатії; різні експерти можуть неоднозначно сприймати поняття "Компетентність експерта”. Для зменшення вказаних недоліків рекомендується використовувати взаємооцінку тільки в тих експертних групах, де експерти добре знають один одного; проводити анонімне анкетування; пояснювати, що результати анкетування будуть використані тільки для коригування оцінок. Отримані характеристики приводяться до одного показника, який характеризує об'єктивну оцінку компетентності експерта.

Статистична оцінка - це оцінка, отримана після статистичної обробки думок експертів про об'єкт оцінки. При цьому властивості об'єктів описуються сукупністю випадкових величин, що порівнюються з відомими (еталонними) значеннями.

Суттєвим недоліком цього методу є те, що при експертних методах часто відома величина відсутня. До того ж на точність експертних оцінок впливає багато чинників об'єктивного і суб'єктивного характеру, внаслідок чого виникають систематичні або випадкові помилки. Тестові оцінки дозволяють за допомогою тестування визначити психофізіологічні особливості експертів. Такі показники є дуже важливими для експертів, що займаються IПВ. Тестування дозволяє оцінити особисті риси, чого не можна зробити ніякими іншими методами.

Недоліком цього методу можна вважати неможливість порівняти дані, отримані методом тестування, $з$ даними, отриманими за допомогою інших об'єктивних методів.

Документальна оцінка - це оцінка експерта на основі документів, які підтверджують його відпові- дність встановленим вимогам. Наприклад, компетентність експерта може бути підтверджена загальними відомостями, які наводяться в анкеті: досвід копією трудової книжки; професійна підготовка дипломом професійної освіти; спеціальна підготовка - атестатом або свідоцтвом встановленого зразка про спеціальну підготовку; підвищення кваліфікації - відповідним свідоцтвом. Документальна оцінка може бути тільки доповненням до інших методів оцінки компетентності експерта і самостійного значення не має. Це обумовлено тим, що частина інформації, яка є в документах, дублює інші оцінки. Всі ці методи досить суб'єктивні, та не можуть самостійно відображати реальний стан компетентності експертів.

Більш об'єктивним було б використання комбінованої методики оцінювання компетентності експертів, яка припускає використання різних методів оцінки з об'єднанням їх у рамках однієї моделі. Оскільки різні методи оцінювання компетентності експертів мають свої переваги і недоліки, то їх спільне використання дозволить посилити переваги i пом'якшити недоліки окремих методів. Використання математичних моделей при цьому може одночасно забезпечити оптимізацію складу експертної групи та вибір раціонального сценарію ІПВ.

Для цього використовують математичні методи та алгоритми, за допомогою яких формуються альтернативні варіанти та здійснюється вибір експертної групи, яка приймає рішення. Це можуть бути методи математичного програмування (динамічного або лінійного), графові моделі, таксономії, теорії ігор, нечітких множин, аналізу ієрархій (MAI) [7; 12-21].

Кожен з методів має свої переваги та недоліки, потребує певних затрат. Тому кожний випадок потребує додаткового аналізу, щоб не підняти вартість прийняття рішення або не знизити його достовірність.

Метою статті $€$ розробка комбінованої методики визначення компетентності експертів при виборі сценарію організації ІПВ.

\section{Виклад основного матеріалу}

Постановка задачі. В загальному вигляді задачу вибору раціонального сценарію прийняття рішення про організацію ІПВ можливо поділити на декілька складових:

- постановку проблеми (завдання);

- вибір органу, що приймає рішення (експерта, або групи експертів);

- вибір сценарію варіантів організації IПВ.

Для кожного типу задач прийняття рішення формується своя система представлення інформації. Кожна задача має свої класифікаційні параметри 
(кількість експертів, кількість сценаріїв ІПВ, кількість критеріїв).

Загальна класифікація задач прийняття рішення при плануванні IПВ та структура ii опису має вигляд, наведений на рис. 1 [12].

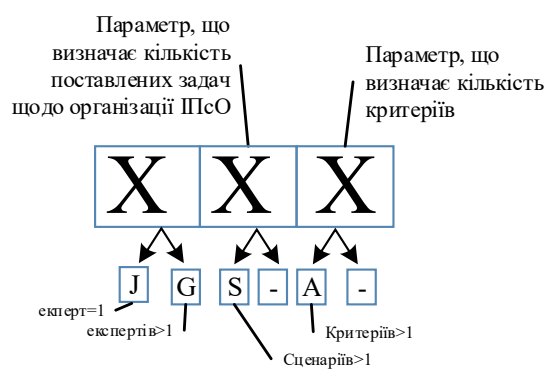

Рис. 1. Загальна класифікація задач прийняття рішення

Перша компонента в опису характеризує кількість експертів: якщо визначено одного експерта, цей параметр в класифікації позначається як $J$. Якщо існує множина експертів, то цей параметр позначається як $\mathbf{G}$ і він $€$ множиною об'єктів $\mathbf{G}=\left\{J_{m}\right\}, m=\overline{1, M}$, де $J_{m}-$ експерт, що вирішує задачу по вибору сценарію організації ІПВ, $M-$ кількість експертів.

Друга складова визначає кількість поставлених задач, або проблемних ситуацій.

Проблемна ситуація $\mathbf{S}$ визначається гіпотетичними ситуаціями $S_{i}$, які описуються як множина задач, яку потрібно вирішити: $\mathbf{S}=\left\{S_{i}\right\}, i=\overline{1, I}$, де I - загальна кількість задач. Якщо існує одна задача $I=1, \mathbf{S}=S_{1}$ і потрібно визначити альтернативні варіанти іiі рішення, таку задачу можна визначити як єдиний інформаційно-психологічний вплив. В цьому випадку в класифікації задачі цей параметр не позначається.

Третя складова класифікації визначає кількість критеріїв, які можуть бути формалізовані як деякі функції, що призначені для визначення кращого (раціонального) рішення. Відомо, що планування ІПВ або ІПсО здійснюється в умовах невизначеної обстановки та залежить від багатьох критеріїв, які являють собою множину об'єктів $\mathbf{A}=\left\{A_{k}\right\}$, $k=\overline{1, K}$, де $A_{k}-$ критерій вибору найкращої альтернативи, $K$ - число критеріїв. Коли задача є багатокритеріальною, цей параметр в класифікації позначається як $\mathbf{A}$, якщо критерій один - він не позначається [12].

Загалом вибір раціонального сценарію ІПВ на противника з урахуванням компетентності експертів може здійснюватися за декілька варіантів.

1. Перший варіант (JA) - один експерт, множина критеріїв. Тобто відбувається індивідуальна експертна оцінка, можливо з урахуванням рішень інших експертів. Цей варіант частіше використовують при:

- узагальненні результатів;

- наданні висновку про роботу інших експертів;

- прогнозуванні розвитку проблемних ситуацій та явищ при організації інформаційно-психологічного впливу.

2. Другий варіант (GA) - декілька (група) експертів, множина критеріїв. Існує декілька сценаріїв групової експертизи:

- в умовах обмеженого часу компетентність експертів не враховується, здійснюється відкрите обговорення щодо вибору сценарію ІПВ і рішення приймається більшістю голосів 3 наявних (призначених) членів експертної групи;

- експерти мають рівні пріоритети (значення компетентності) і серед них не виділений найбільш компетентний експерт, рішення приймається за допомогою методів математичного моделювання;

- 3 урахуванням пріоритетів (компетентності експертів) вважаючи, що для кожного експерта можна зіставити деякий коефіцієнт, значення якого визначає ступінь компетентності експерта серед групи експертів. Тобто має місце вектор коефіцієнтів компетентності експертів. В цьому випадку здійснюється виробка комплексного рішення, яке є композицією різних часток раціональних рішень, які сформовані різними експертами.

Узагальнена схема вибору сценарію ІПВ (рис. 2) включає до себе індивідуальну та (або) групову експертизи, вибір критеріїв та показників ефективності, експертне оцінювання альтернатив та вибір сценарію ІПВ.

Для рішення задач ІПВ більш притаманною $є$ задача типу GA, яка являє собою процедуру групової експертизи за багатьма критеріями. При груповому рішенні необхідно передбачити узгодження отриманої множини рішень через критерій узгодження. Тобто загальна постановка завдання характеризується невизначеністю ситуації, наявністю багатьох критеріїв і базується на методології групового вибору. Відповідно має місце наступна постановка задачі по організації ІПВ.

Вирішується задача підготовки IПВ, $\mathbf{S}=S_{1}$. Icнує множина із $N$ альтернатив $\mathbf{Y}=\left\{Y_{n}\right\}, n=\overline{1, N}$ для вирішення задачі $S_{1}$.

Визначається множина критеріїв вибору найкращої альтернативи $A_{k} \in \mathbf{A}, k=\overline{1, K}$. Для кожного критерію визначена його важливість $\mathbf{B}=\left\{b_{k}\right\}$. Для аналізу варіантів рішень зібрана група з $M$ експертів, де для кожного експерта можна визначити показник пріоритету експерта в групі, який характеризує 
його компетентність (важливість) в галузі ІПВ $W=\left\{w_{1}, w_{2}, \ldots, w_{m}, \ldots, w_{M}\right\}$. При цьому по кожній альтернативі та критерію кожним експертом визначається значення функції переваги $F=\left\{f_{m n k}\right\}$, $k=\overline{1, K}, m=\overline{1, M}, n=\overline{1, N}$.

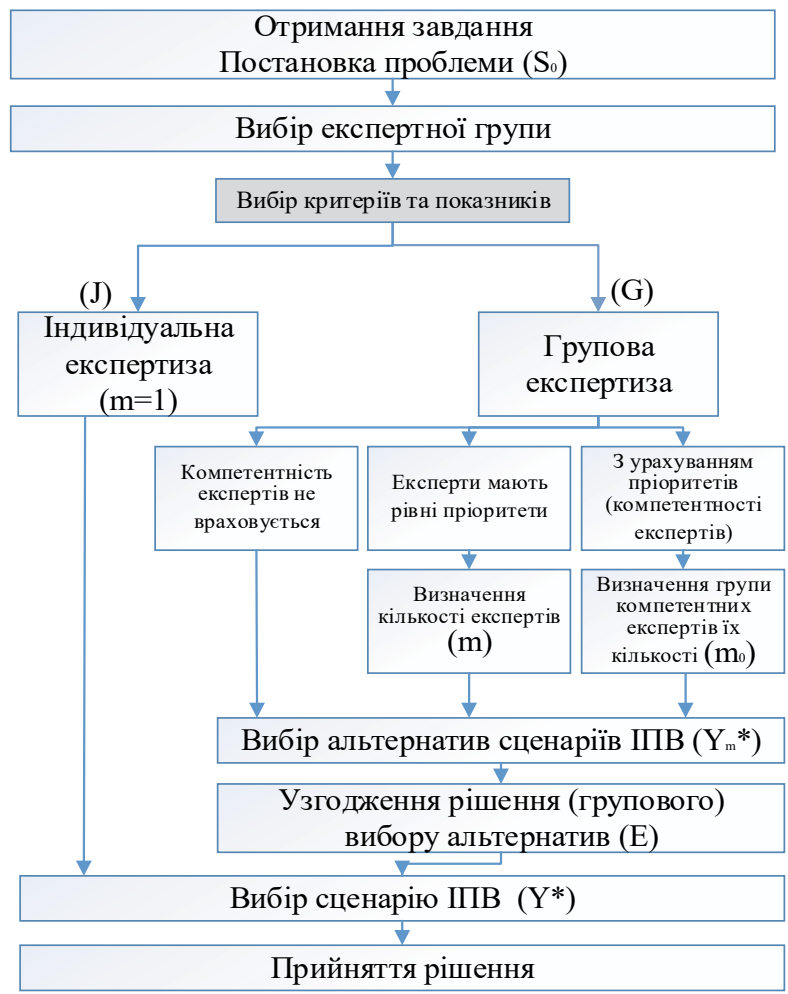

Рис. 2. Загальна схема вибору сценарію ІПВ

На основі визначених значень про локально ефективні варіанти рішення з урахуванням обгрунтованої процедури узгодження здійснюється вибір групового варіанта рішення:

$$
\left(Y_{1}, Y_{2}, \ldots, Y_{m}, \ldots, Y_{M}\right) \rightarrow Y^{*} .
$$

Загальна модель постановки задачі наведена в табл. 1.

Особливістю цієї задачі є врахування показника пріоритету експерта в групі, який характеризує його компетентність (важливість) в галузі IПсО.

Таблиця 1

Модель задачі типу GA

\begin{tabular}{|c|c|c|c|c|c|c|c|c|}
\hline \multicolumn{9}{|c|}{$S_{1}$} \\
\hline \multirow{2}{*}{ 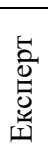 } & \multirow{2}{*}{ 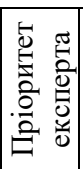 } & \multirow{2}{*}{$\begin{array}{c}\text { Альтерна- } \\
\text { тиви }\end{array}$} & \multicolumn{5}{|c|}{ Критерії } & \multirow{2}{*}{ 可 } \\
\hline & & & $A_{1}$ & $\ldots$ & $A_{k}$ & $\ldots$ & $A_{K}$ & \\
\hline \multirow{5}{*}{$J_{1}$} & \multirow{5}{*}{$w_{1}$} & $Y_{11}$ & $f_{111}$ & $\ldots$ & $f_{11 k}$ & - & $f_{11 K}$ & \multirow{5}{*}{$Y_{1}$} \\
\hline & & $\ldots$ & $\ldots$ & $\ldots$ & $\ldots$ & $\ldots$ & $\ldots$ & \\
\hline & & $Y_{1 n}$ & $f_{1 n 1}$ & $\cdots$ & $f_{1 n k}$ & $\cdots$ & $f_{1 n K}$ & \\
\hline & & $\ldots$ & $\ldots$ & $\ldots$ & $\ldots$ & $\ldots$ & $\ldots$ & \\
\hline & & $Y_{1 N}$ & $f_{1 N 1}$ & $\cdots$ & $f_{1 N k}$ & & $f_{1 N K}$ & \\
\hline$\ldots$ & $\ldots$ & $\ldots$ & $\ldots$ & $\ldots$ & $\ldots$ & & $\ldots$ & $\ldots$ \\
\hline$J_{m}$ & $w_{m}$ & $Y_{m 1}$ & $f_{m 11}$ & $\cdots$ & $f_{m 1 k}$ & 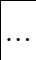 & $f_{m 1 K}$ & $Y_{m}$ \\
\hline
\end{tabular}

Закінчення табл. 1

\begin{tabular}{|c|c|c|c|c|c|c|c|c|}
\hline & & $\ldots$ & $\ldots$ & $\ldots$ & $\ldots$ & $\ldots$ & $\ldots$ & \\
\hline & & $Y_{m n}$ & $f_{m n 1}$ & $\ldots$ & $f_{m n k}$ & $\ldots$ & $f_{m n K}$ & \\
\hline & & $\ldots$ & $\ldots$ & $\ldots$ & $\ldots$ & $\ldots$ & $\ldots$ & \\
\hline & & $Y_{m N}$ & $f_{m N 1}$ & $\cdots$ & $f_{m N k}$ & $\cdots$ & $f_{m N K}$ & \\
\hline$\ldots$ & $\ldots$ & $\ldots$ & $\ldots$ & $\ldots$ & $\ldots$ & $\ldots$ & $\ldots$ & $\ldots$ \\
\hline \multirow{5}{*}{$J_{M}$} & \multirow{5}{*}{$w_{M}$} & $Y_{M 1}$ & $f_{M 11}$ & & $f_{M 1 k}$ & 4 & $f_{M 1 K}$ & \multirow{5}{*}{$Y_{M}$} \\
\hline & & & $\ldots$ & & $\ldots$ & $\ldots$ & $\ldots$ & \\
\hline & & $Y_{M n}$ & $f_{M n 1}$ & & $f_{M n k}$ & . & $f_{M n K}$ & \\
\hline & & 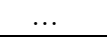 & $\ldots$ & & $\ldots$ & $\ldots$ & $\ldots$ & \\
\hline & & $Y_{M N}$ & $f_{M N 1}$ & $\cdots$ & $f_{M N k}$ & .. & $f_{M N K}$ & \\
\hline \multicolumn{3}{|c|}{ Пріоритети критеріїв } & $b_{1}$ & $\cdots$ & $b_{k}$ & .. & $b_{K}$ & \\
\hline
\end{tabular}

Оцінювання компетентності експертів при визначенні кращого сценарію ІПВ має враховувати їх узагальнені індивідуальні параметри: досвід, рівень знань по проблемі, кваліфікацію, освіту, та інші [12]. Окрім того, для оцінювання компетентності експертів, що здійснюють вибір сценарію IПВ, необхідно враховувати нестандартні характеристики, такі як творче мислення, багатоваріантність рішень, гнучкість, здібність до абстрактного мислення, креативність. Показники творчого мислення визначаються по успішності складання тестів на креативність.

Для оцінювання компетентності експертів при виборі сценарію пропонується ввести комбінований показник пріоритету (компетентності) експертів $W_{\Sigma m}$, який буде включати об'єктивну $W_{o m}$ та суб'єктивну $W_{c m}$ оцінки компетентності експерта.

Для визначення об'єктивного показника компетентності експерта $W_{\text {om }}$ потрібно оцінити вагу кожного критерію, що впливає на компетентність експерта, через вагові коефіцієнти. При цьому деякі коефіцієнти можуть бути отримані на основі тестової оцінки (в більшості такі, що відображають психофізіологічні особливості експертів). Надалі, наприклад за методом MAI, визначається пріоритет кожного експерта з урахуванням всіх критеріїв.

Найбільш простою та зручною формою для визначення $W_{c m} \in$ самооцінювання. Включення в процес вибору експертної групи самооцінювання є важливою складовою. При цьому мотиваційний ефект для експерта стає значно вище.

Визначимо комбінований показник компетентності експерта в групі $W_{\Sigma m}$ у вигляді:

$$
\begin{gathered}
W_{\Sigma m}=b_{o} W_{\text {om }}+b_{c} W_{c m}, \\
W_{\text {om }} \in[0,1], W_{c m} \in[0,1], b_{c}+b_{o}=1,
\end{gathered}
$$

де $b_{c}, b_{o}$ - вагові коефіцієнти оцінок експертів. 


$$
\begin{gathered}
0 \leq W_{\Sigma m} \leq 1, \\
\sum_{m=1}^{M} W_{\Sigma m}=1 .
\end{gathered}
$$

Таким чином, в статті потрібно визначити порядок оцінювання компетентності експертів та їх оптимального складу для прийняття рішення щодо організації ІПВ.

\section{Методика оцінювання компетентності експертів}

У загальному вигляді методика оцінювання компетентності експертів при виборі сценарію прийняття рішення на організацію ІПВ буде складатись 3 декількох етапів.

На першому етапі - визначення групи експертів (визначення компетентності експертів та їх чисельності), тобто:

1) структуризація процедури прийняття рішень у вигляді ієрархічної структури з декількома рівнями (рис. 3);

2) визначення вагових коефіцієнтів за всіма критеріями, що впливають на компетентність кожного експерта;

$3)$ розрахування вагових оцінок $m$-го експерта по $K$ критеріям;

4) обчислення вектору пріоритетів критеріїв;

5) обчислення показника $W_{\text {om }}$ об'єктивної оцінки компетентності експерта з урахуванням пріоритету для кожного з критеріїв;

6) визначення суб'єктивної оцінки $W_{c m}$;

7) обчислення комбінованого вектору компетентності експертів $W_{\Sigma}=\left\{W_{\Sigma m}\right\}$;

8) розрахунок необхідної чисельності експертів (m) для проведення експертизи об'єктів;

9) визначення групи експертів з максимальним коефіцієнтом компетентності.

На другому етапі - визначення узгодженості суджень експертів.

У випадку, якщо узгодженість експертів не відповідає вимогам, заново уточняється вектор пріоритету критеріїв при виборі експертів в залежності від задачі інформаційно-психологічного впливу, здійснюється якісна та чисельна оптимізація групи експертів. Наприклад, якщо планується задача інформаційного впливу через засоби масової інформації, то і критерій, що визначає креативність та нестандартність мислення експертів, повинен мати вищий пріоритет, ніж, наприклад, наявність наукових праць.

Дана методика є комбінованою за сумісним використанням показників об'єктивного та суб'єктивного оцінювання компетентності експертів 3 подальшою оптимізацією чисельності найбільш компетентних експертів та узгодження їх рішень.
Розглянемо технологію застосування комбінованої методики для вибору групи експертів. На першому етапі визначимо компетентність експертів та їх чисельність за кроками.

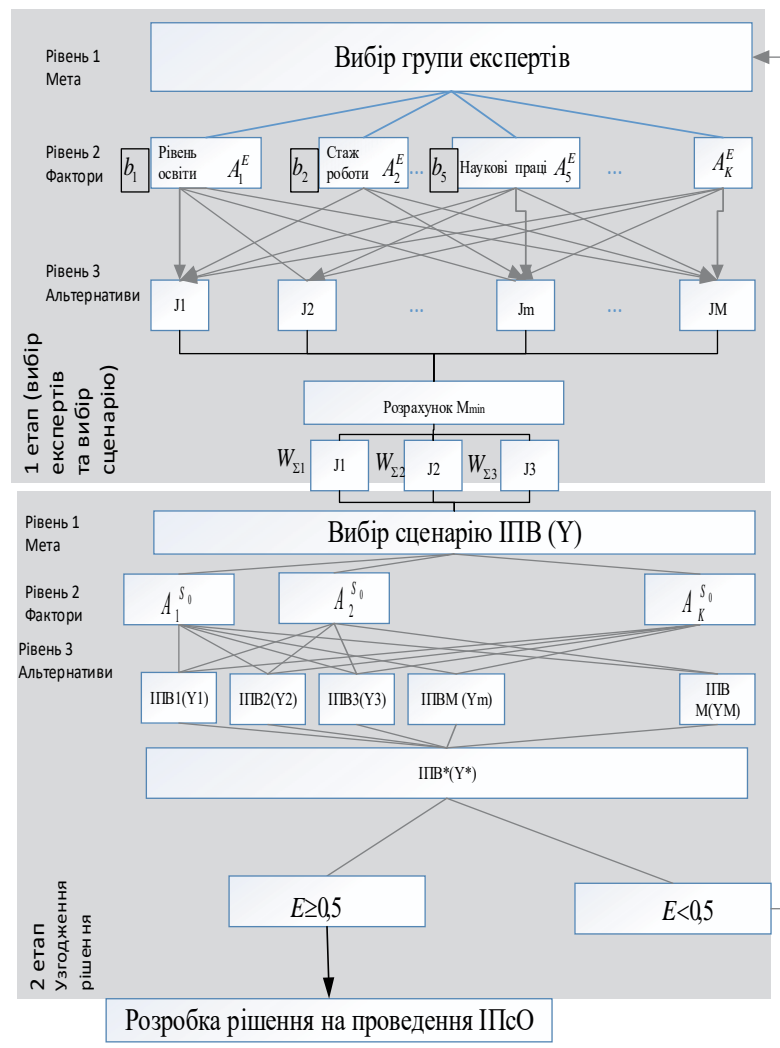

Рис. 3. Ієрархічна структура процедури прийняття рішень на проведення IПсО з оптимізацією складу та чисельності експертів

1-й крок. Побудова ієрархії здійснюється 3 вершини - цілі аналізу (в даному випадку - це вибір $m$ експертів), через проміжні рівні (критерії, за якими проводиться порівняння варіантів) до нижнього рівня (який $є$ перерахуванням альтернатив) (рис. 3).

2-й крок. При оцінюванні компетентності експертів в галузі IПсО необхідно враховувати наступні критерії $A_{k}^{E}, k=\overline{1,7}$ : спеціалізацію експерта, стаж i досвід його роботи в даній області, наукову кваліфікацію, наявність наукових праць 3 проблематики проведення експертизи, нестандартність мислення (табл. 2, індекс $E$ символізує розгляд властивостей експертів).

Таблиця 2

Вагові коефіцієнти (бали) професійної компетентності експерта за визначеними критеріями

\begin{tabular}{|c|c|c|c|c|}
\hline \multicolumn{2}{|c|}{ Критерії } & \multicolumn{3}{|c|}{$\begin{array}{c}\text { Значення вагового коефіцієнта } \\
\text { критерію }\left(\psi_{m k}\right)\end{array}$} \\
\hline $\begin{array}{c}\text { Рівень освіти } \\
\text { експертів }\end{array}$ & $A_{1}^{E}$ & Середня & $\begin{array}{c}\text { Середня } \\
\text { спеціальна }\end{array}$ & Вища \\
\cline { 2 - 5 } & 0,2 & 0,3 & 0,5 \\
\hline Стаж роботи & $A_{2}^{E}$ & $\begin{array}{c}\text { від 1 до } \\
5 \text { років }\end{array}$ & $\begin{array}{c}\text { від 5 до } 10 \\
\text { років }\end{array}$ & $\begin{array}{c}\text { понад } \\
10 \text { років }\end{array}$ \\
\hline
\end{tabular}


Закінчення табл. 2

\begin{tabular}{|c|c|c|c|c|}
\hline & & 0,2 & 0,3 & 0,5 \\
\hline \multirow{2}{*}{\begin{tabular}{|c|} 
Досвід роботи \\
за профілем \\
проведення \\
експертизи
\end{tabular}} & \multirow{2}{*}{$A_{3}^{E}$} & $\begin{array}{l}\text { відсут- } \\
\text { ній }\end{array}$ & $\begin{array}{l}\text { від } 1 \text { до } 5 \\
\text { років }\end{array}$ & $\begin{array}{c}\text { понад } \\
5 \text { років }\end{array}$ \\
\hline & & 0 & 0,4 & 0,6 \\
\hline \multirow{3}{*}{$\begin{array}{c}\text { Наукова } \\
\text { кваліфікація }\end{array}$} & \multirow{3}{*}{$A_{4}^{E}$} & \multicolumn{3}{|c|}{$\begin{array}{c}\text { Наявність наукового ступеня, } \\
\text { вченого звання }\end{array}$} \\
\hline & & - & \begin{tabular}{c|} 
кандидат \\
наук
\end{tabular} & доктор наук \\
\hline & & 0 & 0,4 & 0,6 \\
\hline \multirow{2}{*}{$\begin{array}{c}\text { Наявність } \\
\text { наукових } \\
\text { праць за } \\
\text { останні } 5 \\
\text { років }\end{array}$} & \multirow[b]{2}{*}{$A_{5}^{E}$} & відсутні & $\begin{array}{c}\text { до } 5 \\
\text { статей }\end{array}$ & понад 5 статей \\
\hline & & 0 & 0,4 & 0,6 \\
\hline \multirow{3}{*}{\begin{tabular}{|c} 
Оцінка \\
гнучкості \\
мислення \\
(дивергентне \\
мислення - \\
багатоваріан- \\
тне \\
мислення)
\end{tabular}} & \multirow{3}{*}{$A_{6}^{E}$} & \multicolumn{3}{|c|}{$\begin{array}{c}3 \text { використанням тестів } \\
\text { діагностування креативного } \\
\text { мислення (Тест Торренса [23]) }\end{array}$} \\
\hline & & $\begin{array}{c}\text { Погано, } \\
\text { нижче } \\
\text { норми }\end{array}$ & Норма & $\begin{array}{l}\text { Вище норми, } \\
\text { відмінно }\end{array}$ \\
\hline & & $\begin{array}{c}\text { Менше } \\
0,3\end{array}$ & $0,3-0,6$ & $0,6-1$ \\
\hline \multirow{3}{*}{\begin{tabular}{|c|} 
Оцінка \\
зосереджено- \\
сті \\
(конвергент- \\
ність \\
мислення) \\
[24]
\end{tabular}} & \multirow{3}{*}{$A_{7}^{E}$} & \multicolumn{3}{|c|}{$\begin{array}{c}3 \text { використанням тестів } \\
\text { психодіагностування }\end{array}$} \\
\hline & & $\begin{array}{c}\text { Погано, } \\
\text { нижче } \\
\text { норми }\end{array}$ & Норма & $\begin{array}{l}\text { Вище норми, } \\
\text { відмінно }\end{array}$ \\
\hline & & $\begin{array}{c}\text { Менше } \\
0,3\end{array}$ & $0,3-0,6$ & $0,6-1$ \\
\hline
\end{tabular}

Закінчення табл. 3

\begin{tabular}{|c|c|c|c|c|c|c|c|c|}
\hline$J_{8}$ & 0,3 & 0,5 & 0 & 0 & 0 & 0,9 & 0,5 & 2,2 \\
\hline$J_{9}$ & 0,2 & 0,2 & 0,2 & 0 & 0,6 & 0,99 & 0,4 & 2,59 \\
\hline$J_{10}$ & 0,2 & 0,5 & 0 & 0 & 0 & 0,9 & 0,5 & 2,1 \\
\hline$\sum$ & 4 & 3,8 & 2,6 & 2,00 & 3,60 & 5,29 & 3,81 & 25,1 \\
\hline
\end{tabular}

4-й крок. Визначення пріоритетів критеріїв за методом MAI (табл. 4):

$$
B=\left\{b_{k}\right\}, k=\overline{1, K}, \sum_{k=1}^{K} b_{k}=1 .
$$

Таблиця 4 Матриця парних порівнянь критеріїв

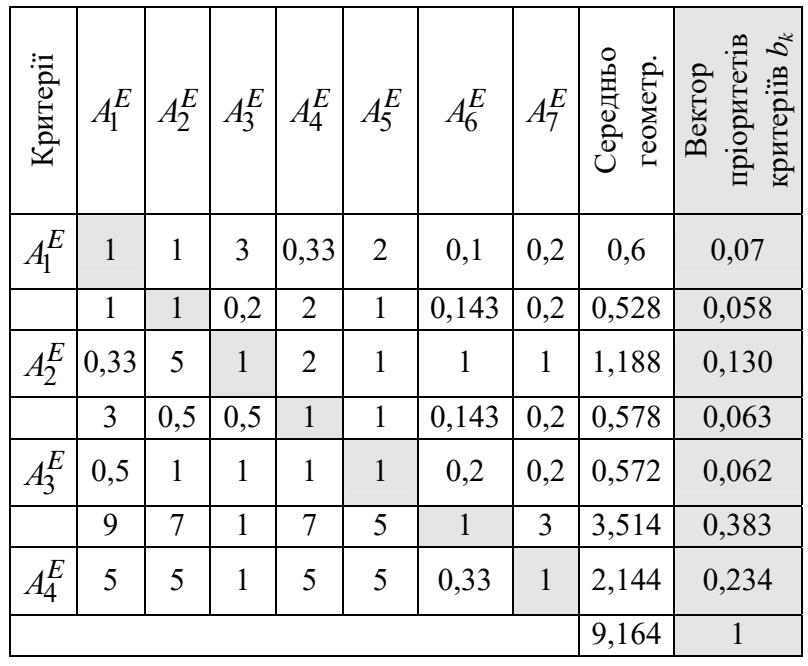

5-й крок. Обчислення нормованого об'єктивного показника $W_{\text {om }}$ компетентності кожного $m$-го експерта без урахування пріоритету та з урахуванням пріоритету кожного 3 критеріїв, застосовуючи наступні формули:

- не враховуючи пріоритет критеріїв

$$
\Psi=\left|\begin{array}{l}
\psi_{12} \psi_{12} \ldots \psi_{1 k} \\
\psi_{21} \psi_{22} \ldots \psi_{2 k} \\
\psi_{m 1} \psi_{m 2} \ldots \psi_{m k} \\
\cdots \ldots \ldots \ldots \ldots . . . \\
\psi_{M 1} \psi_{M 2} \ldots \psi_{M K}
\end{array}\right| .
$$

В табл. 3 наведено приклад оцінювання вагових коефіцієнтів кожного 3 10-ти експертів по 7 критеріям.

Таблиця 3

\begin{tabular}{|c|c|c|c|c|c|c|c|c|}
\hline \multirow{2}{*}{$\begin{array}{l}\text { Екс- } \\
\text { перт }\end{array}$} & \multicolumn{7}{|c|}{$\psi_{m k}$} & \multirow{2}{*}{$\sum_{m=1}^{M} \psi_{m k}$} \\
\hline & $A_{1}^{E}$ & $A_{2}^{E}$ & $A_{3}^{E}$ & $A_{4}^{E}$ & $A_{5}^{E}$ & $A_{6}^{E}$ & $A_{7}^{E}$ & \\
\hline$J_{1}$ & 0,5 & 0,6 & 0,6 & 0,6 & 0,6 & 0,1 & 0,2 & 3,2 \\
\hline$J_{2}$ & 0,5 & 0,5 & 0,6 & 0,6 & 0,6 & 0,1 & 0,1 & 3 \\
\hline$J_{3}$ & 0,5 & 0,5 & 0,4 & 0,4 & 0,6 & 0,5 & 0,2 & 3,1 \\
\hline$J_{4}$ & 0,5 & 0,3 & 0,4 & 0,4 & 0,6 & 0,2 & 0,8 & 3,2 \\
\hline$J_{5}$ & 0,5 & 0,3 & 0 & 0 & 0,2 & 0,4 & 0,2 & 1,6 \\
\hline$J_{6}$ & 0,5 & 0,2 & 0 & 0 & 0,2 & 0,4 & 0,41 & 1,71 \\
\hline$J_{7}$ & 0,3 & 0,2 & 0,4 & 0 & 0,2 & 0,8 & 0,5 & 2,4 \\
\hline
\end{tabular}

Оцінки ваги кожного експерта (приклад)

де $\beta_{m k}-$ значення вагового коефіцієнта виходячи 3 компетентності експертів:

$$
\beta_{m k}=\frac{\psi_{m k}}{\sum_{m=1}^{M} \psi_{m k}},
$$

- 3 урахуванням пріоритету критеріїв. Для отримання глобального показника об'єктивної оцінки експертів $W_{o m}^{*}$ необхідно для кожного з експертів підсумувати нормалізовані критерії, помножені на свої вектори пріоритетів, отримані за методом MAI $[1 ; 4 ; 6]$. Альтернатива з найбільшим значенням глобального пріоритету $є$ кращою для експерта (табл. 5). 


$$
W_{\text {om }}^{*}=\frac{\sum_{k=1}^{K} \gamma_{m k}}{\sum_{m=1}^{M} \sum_{k=1}^{K} \gamma_{m k}}, \sum_{m=1}^{M} W_{o m}^{*}=1,
$$

де $\gamma_{m k}$ значення вагового коефіцієнта виходячи 3 компетентності експертів з урахуванням пріоритету критеріїв:

$$
\gamma_{m k}=b_{k} \beta_{m k}
$$

Таблиця 5

Приклад розрахунку нормованого показника компетентності $W_{\text {om }}$ для кожного експерта

без урахування пріоритетів критеріїв

\begin{tabular}{|c|c|c|c|c|c|c|c|c|}
\hline $\begin{array}{c}\text { Екс- } \\
\text { перт }\end{array}$ & \multicolumn{7}{|c|}{$\beta_{m k}$} & \multirow{2}{*}{$W_{\text {от }}$} \\
\cline { 2 - 9 } & $A_{1}^{E}$ & $A_{2}^{E}$ & $A_{3}^{E}$ & $A_{4}^{E}$ & $A_{5}^{E}$ & $A_{6}^{E}$ & $A_{7}^{E}$ & \\
\hline$J_{1}$ & 0,125 & 0,158 & 0,231 & 0,3 & 0,167 & 0,019 & 0,052 & 0,150 \\
\hline$J_{2}$ & 0,125 & 0,132 & 0,231 & 0,3 & 0,167 & 0,019 & 0,026 & 0,143 \\
\hline$J_{3}$ & 0,125 & 0,132 & 0,154 & 0,2 & 0,167 & 0,095 & 0,052 & 0,132 \\
\hline$J_{4}$ & 0,125 & 0,079 & 0,154 & 0,2 & 0,167 & 0,038 & 0,210 & 0,139 \\
\hline$J_{5}$ & 0,125 & 0,079 & 0 & 0 & 0,056 & 0,076 & 0,052 & 0,055 \\
\hline$J_{6}$ & 0,125 & 0,053 & 0 & 0 & 0,056 & 0,076 & 0,108 & 0,059 \\
\hline$J_{7}$ & 0,075 & 0,053 & 0,154 & 0 & 0,056 & 0,151 & 0,131 & 0,088 \\
\hline$J_{8}$ & 0,075 & 0,132 & 0 & 0 & 0 & 0,170 & 0,131 & 0,073 \\
\hline$J_{9}$ & 0,05 & 0,053 & 0,077 & 0 & 0,167 & 0,187 & 0,105 & 0,091 \\
\hline$J_{10}$ & 0,05 & 0,132 & 0 & 0 & 0 & 0,17 & 0,131 & 0,069 \\
\hline $\begin{array}{c}\text { Сума } \\
\text { балів }\end{array}$ & 1 & 1 & 1 & 1 & 1 & 1 & 1 & 1 \\
\hline
\end{tabular}

Ваги експертів за кожним критерієм з розрахунком $W_{o m}$ по десяти експертам наведено в табл. 6.

Таблиця 6

Приклад результатів обчислення глобальних пріоритетів $W_{\text {om }}^{*}$ з урахуванням

\begin{tabular}{|c|c|c|c|c|c|c|c|c|c|}
\hline \multirow{2}{*}{ 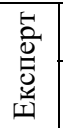 } & \multicolumn{7}{|c|}{$\gamma_{m k}$} & \multirow{3}{*}{$\sum_{k=1}^{K} \beta_{m k}$} & \multirow{3}{*}{$W_{\text {om }}^{*}$} \\
\hline & $A_{1}^{E}$ & $A_{2}^{E}$ & $A_{3}^{E}$ & $A_{4}^{E}$ & $A_{5}^{E}$ & $A_{6}^{E}$ & $A_{7}^{E}$ & & \\
\hline$b_{k}$ & 0,070 & 0,058 & 0 , & 0,063 & 0,062 & 0,383 & 0,234 & & \\
\hline$J_{1}$ & 0,009 & 0,009 & 0,03 & 0,019 & 0,01 & 0,007 & 0,012 & 0,097 & 0,107 \\
\hline$J_{2}$ & 0,009 & 0,008 & 0,03 & 0,019 & 0,01 & 0,007 & 0,006 & 0,089 & 0,099 \\
\hline$J_{3}$ & 0,009 & 0,008 & 0,02 & 0,013 & 0,01 & 0,036 & 0,012 & 0,108 & 0,120 \\
\hline \begin{tabular}{l|l}
$J_{4}$ \\
\end{tabular} & 0,009 & 0,005 & 0,02 & 0,013 & 0,01 & 0,014 & 0,049 & 0,120 & 0,133 \\
\hline \begin{tabular}{l|l}
$J_{5}$ \\
\end{tabular} & 0,009 & 0,005 & 0 & 0 & 0,003 & 0,029 & 0,012 & 0,058 & 0,065 \\
\hline$J_{6}$ & 0,009 & 0,003 & 0 & 0 & 0,003 & 0,029 & 0,025 & 0,069 & 0,077 \\
\hline$J_{7}$ & 0,005 & 0,003 & 0,02 & 0 & 0,003 & 0,058 & 0,031 & 0,120 & 0,134 \\
\hline \begin{tabular}{l|l}
$J_{8}$ \\
\end{tabular} & 0,001 & 0,001 & 0 & 0 & 0 & 0,005 & 0,002 & 0,008 & 0,009 \\
\hline$J_{9}$ & 0,003 & 0,003 & 0,01 & 0 & 0,01 & 0,072 & 0,025 & 0,123 & 0,137 \\
\hline$J_{10}$ & 0,003 & 0,008 & 0 & 0 & 0 & 0,065 & 0,031 & 0,107 & 0,119 \\
\hline уалів & & 0,0 & 0,13 & ho & 0,062 & 0,323 & 0,2 & 0,899 & 1 \\
\hline
\end{tabular}

пріоритетів критеріїв

Як бачимо 3 таблиць, якщо надано пріоритет критеріям, які відповідають за нестандартне рішення, то пріоритет отримають експерти 3 невисоким рівнем освіти, але з високими показниками нешаб- лонного мислення. Такий підхід є важливим при виборі нестандартних сценаріїв ІПВ, тобто в залежності від креативності завдання може змінюватися експертна група. При цьому в групу можуть увійти молоді спеціалісти, які мають досвід рішення подібного класу нестандартних задач, але не мають наукових ступенів та вчених звань.

На 6-му кроці здійснюється визначення суб'єктивної оцінки $W_{c m}$ через самооцінювання експертів. Найбільш проста і зручна форма самооцінювання - сукупний індекс, розрахований на підставі оцінки експертами своїх знань, досвіду і здібностей за ранговою шкалою з позиціями “високий” - числове значення 1, “середній” - 0,5, “низький” 0 . У такому разі сукупний індекс-коефіцієнт рівня компетентності експерта обчислюється за формулами (7-8). Отримати первинні числові значення самооцінки для розрахунку індексу компетентності експертів можна за допомогою табл. 7, де індекси CE вказують на вирішення задачі самооцінювання експерта.

Таблиця 7

Значення самооцінки для розрахунку індексу компетентності

\begin{tabular}{|c|c|c|c|}
\hline $\begin{array}{c}\text { Критерії } \\
\text { самооціню- } \\
\text { вання }\end{array}$ & $\begin{array}{c}\text { Теоретичні } \\
\text { знання } A_{1}^{C E}\end{array}$ & $\begin{array}{c}\text { Практичний } \\
\text { досвід } A_{2}^{C E}\end{array}$ & $\begin{array}{c}\text { Здатність } \\
\text { до прогнозу } \\
A_{3}^{C E}\end{array}$ \\
\hline \multicolumn{3}{|c|}{ Значення вагового коефіцієнта критерію } \\
\multicolumn{3}{|c|}{ самооцінювання $\left(\psi_{m k}^{c}\right)$} \\
\hline Низький & 0 \\
\hline Середній & 0,5 \\
\hline Високий & 1 \\
\hline
\end{tabular}

Приклад розрахунків наведено в табл. 8.

Таблиця 8

Приклад розрахунку суб'єктивної оцінки

\begin{tabular}{|c|c|c|c|c|c|c|c|c|}
\hline \multirow[b]{2}{*}{ 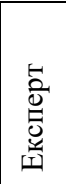 } & \multicolumn{3}{|c|}{$\psi_{m k}^{c}$} & \multicolumn{3}{|c|}{$\beta_{m k}^{C}$} & \multirow[b]{2}{*}{$\sum^{K} \beta_{m k}^{C}$} & \multirow[b]{2}{*}{$W_{c m}$} \\
\hline & $A_{1}^{C E}$ & $A_{2}^{C E}$ & $A_{3}^{C E}$ & $A_{1}^{C E}$ & $A_{2}^{C E}$ & $A_{3}^{C E}$ & & \\
\hline$J_{1}$ & 1 & 0 & 1 & 0,149 & 0 & 0,118 & 0,267 & 0,089 \\
\hline$J_{2}$ & 1 & 0 & 1 & 0,149 & 0 & 0,118 & 0,267 & 0,089 \\
\hline$J_{3}$ & 1 & 0,5 & 0,5 & 0,149 & 0,091 & 0,059 & 0,299 & 0,1 \\
\hline$J_{4}$ & 1 & 0,5 & 1 & 0,149 & 0,091 & 0,118 & 0,358 & 0,119 \\
\hline$J_{5}$ & 1 & 0 & 1 & 0,149 & 0,000 & 0,118 & 0,267 & 0,089 \\
\hline$J_{6}$ & 0,5 & 0,5 & 0,5 & 0,075 & 0,091 & 0,059 & 0,224 & 0,075 \\
\hline$J_{7}$ & 0,3 & 1 & 1 & 0,045 & 0,182 & 0,118 & 0,344 & 0,115 \\
\hline$J_{8}$ & 0,5 & 1 & 1 & 0,075 & 0,182 & 0,118 & 0,374 & 0,125 \\
\hline$J_{9}$ & 0,2 & 1 & 0,5 & 0,03 & 0,182 & 0,059 & 0,27 & 0,09 \\
\hline$J_{10}$ & 0,2 & 1 & 1 & 0,03 & 0,182 & 0,118 & 0,329 & 0,11 \\
\hline $\begin{array}{l}\text { Сума } \\
\text { балів }\end{array}$ & 6,7 & 5,5 & 8,5 & 1 & 1 & 1 & 3 & 1 \\
\hline
\end{tabular}
експертів $W_{c m}$ 
При відборі експертів методом самооцінки виникає проблема ії завищення. Проте, на думку фахівців, “досвід численних експертиз і у нас, і за кордоном показує, що групи з високою самооцінкою, як правило, помиляються у своїх судженнях при проведенні експертизи менше інших" [12].

Відповідно на сьомому кроці визначається $W_{\Sigma m}$ за формулами (2-4).

Якщо прийняти, що $b_{o}=0,3, b_{c}=0,7$, отримаємо наступні результати (табл. 9).

Комбінований показник компетентності експерта в групі $W_{\Sigma m} 3$ результатами ранжування експертів

\begin{tabular}{|c|c|c|c|c|c|c|c|c|c|c|c|}
\hline 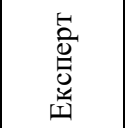 & J1 & $\mathrm{J} 2$ & $\mathrm{~J} 3$ & $\mathrm{~J} 4$ & J5 & J6 & J7 & J8 & J9 & $\mathrm{J} 10$ & $\sum_{m=1}^{M} W_{\Sigma m}$ \\
\hline$W_{\Sigma m}$ & $\begin{array}{l}2 \\
0 \\
0 \\
0\end{array}$ & \begin{tabular}{l}
+ \\
\multirow{0}{0}{} \\
0
\end{tabular} & 훙 & $\frac{\stackrel{g}{0}}{0}$ & $\underset{0}{\mathbb{N}}$ & 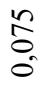 & $\frac{\stackrel{n}{1}}{0}$ & $\frac{n}{2}$ & $\frac{\stackrel{\overbrace{}}{I}}{0}$ & $\frac{9}{\partial}$ & 1 \\
\hline $\begin{array}{c}\text { Ранг } \\
\text { експерта }\end{array}$ & 7 & 9 & 6 & 5 & 10 & 8 & 2 & 1 & 3 & 4 & \\
\hline
\end{tabular}

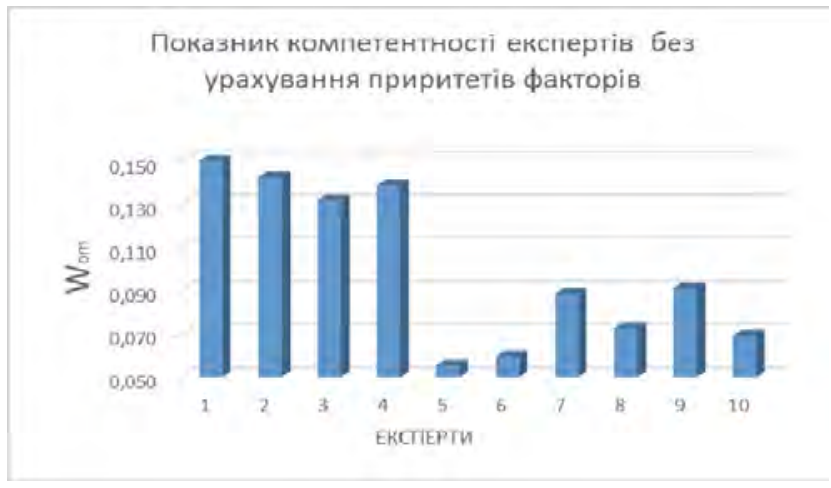

a

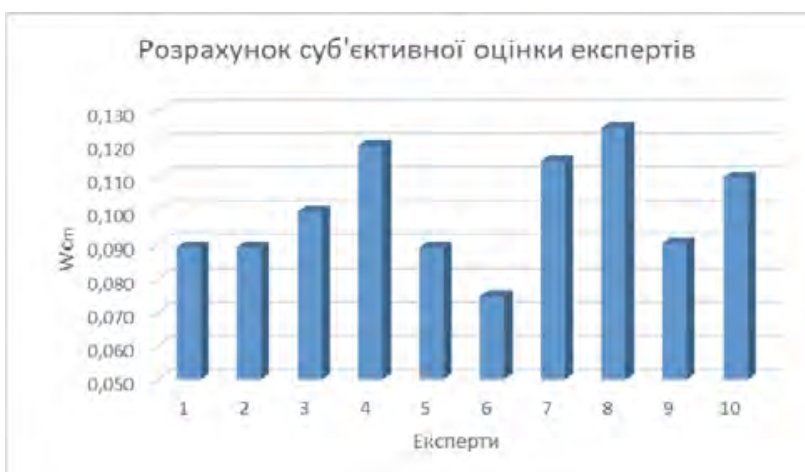

B
За результатами таблиць (5-6; 8-9) побудуємо діаграми (рис. 4).

На восьмому кроці розраховується мінімальна чисельність експертів $m_{0}$ для проведення експертизи сценаріїв ІПВ.

При визначенні чисельності групи експертів враховуються наступні вимоги:

- чисельність не має бути дуже мала, щоб не втратити смисловий зміст процедури формування експертних оцінок;

- якщо група експертів завелика, будуть мати місце наступні недоліки:

а) трудомісткість організації експертизи, яка пов'язана з обробкою результатів;

б) важкість координації роботи групи;

в) менш вагомим буде вплив оцінки кожного експерта на групову оцінку.

В практиці проведення експертизи існують граничні оцінки чисельності групи експертів. Вони залежать від складності та чисельності задач й сценаріїв ІПВ [25]. Вибір методу відбору генеральної сукупності експертів - окрема тема досліджень. При проведенні ІПВ важливо, щоб у в якості експертів були залучені фахівці з різними характеристиками, тобто сукупність експертів має бути неоднорідною.

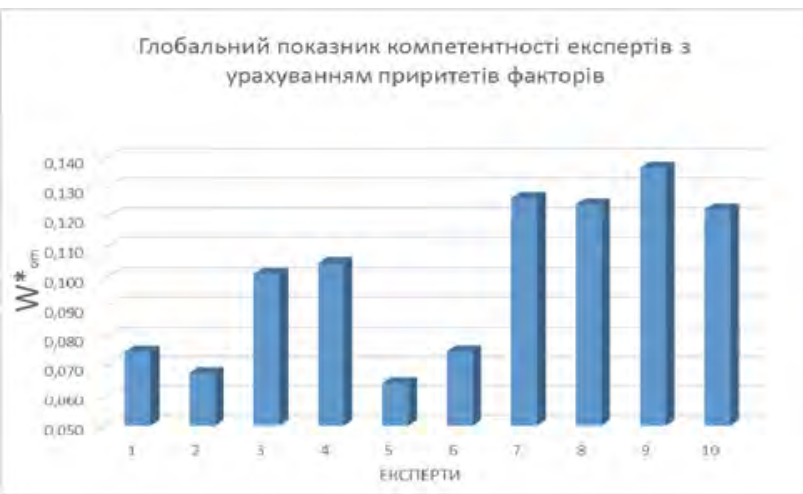

6

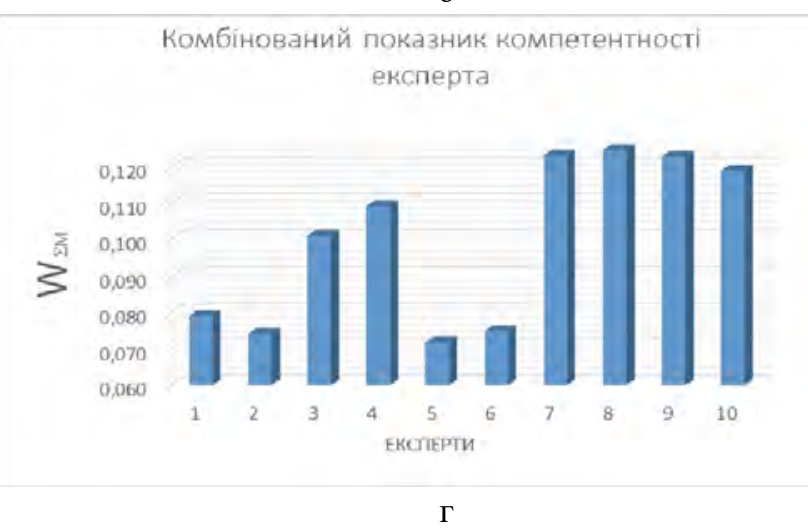

Рис. 4. Послідовність експертів за рейтингом з урахуванням пріоритету критеріїв

Важлива наявність в групі фахівців $з$ різним типом мислення (дивергентне або конвергентне мислення) в залежності від завдання. Тобто існує варі- ативність, яка пов'язана 3 характеристиками одиниць в генеральній сукупності, з якої здійснюється вибірка. При цьому можливо використання страти- 
фікованою (по стратам (шарам)) вибіркою експертів.

Для обчислення мінімальної кількості $m_{0}$ експертів можливо скористатися формулою розрахунку необхідного об'єму стратифікованої вибірки [25]:

$$
m_{0}=\frac{t^{2} \sigma^{-2} M}{\Delta^{2} M+t^{2} \sigma^{-2}},
$$

де значення $t$ отримується 3 таблиці Стьюдента (для рівня достовірності 0,997 відповідно $t=3$ ); $\sigma^{2}=0,003397$ - вибіркова дисперсія для даних, наведених в [26]; $M=10$ - генеральна сукупність експертів; $\Delta=0,07$ - гранична помилка вибірки.

Підставляючи ці дані в (12) отримаємо $m_{0}=3,841898$. Тобто мінімальна необхідна кількість експертів в цьому випадку $m_{0}=4$. Для наведеного прикладу з урахуванням (12) до цієї групи будуть зараховані експерт 7, експерт 8 , експерт 9 i експерт 10, які мають найбільший пріоритет $W_{\Sigma m}$. Надалі здійснюється вибір сценаріїв планування IПВ кожним експертом окремо. Можливо два варіанта прийняття групового рішення: за більшістю голосів, або за допомогою математичних алгоритмів. Якщо брак часу, то можливо скористатися першим способом, але цей спосіб не завжди відповідає дійсності. Саме тому важливо на етапі аналізу і обробки експертних оцінок не отримання індивідуальних оцінок кожного обраного експерта, а формування групової оцінки, яка визначається за принципом узгодження думок експертів. При оцінці й ранжируванні альтернатив планування ІПВ експерти можуть розходиться в думках з їх ефективності. У зв'язку з цим виникає необхідність кількісної оцінки тих висловлювань, які були сформульовані експертами при виборі альтернатив. Така кількісна оцінка визначає ступінь згоди експертів. Отримання кількісної міри узгодженості думок експертів дозволяє обгрунтовано проводити вибір найбільш ефективного рішення щодо планування IПВ і точніше інтерпретувати причини в розбіжності думок експертів. У якості кількісної міри будемо застосовувати коефіцієнт конкордації Кендала $E$. Він являє собою деяке число від 0 до 1 , яке характеризує узгодженість думок експертів (у вигляді рангів) за сукупністю критеріїв. Коефіцієнт конкордації Кендала розраховується наступним чином [12]:

$$
E=\frac{12 S}{\left(m_{0}\right)^{2}\left(n^{3}-n\right)},
$$

де $S$ - сума квадратів різниці рангів (відхилення від середнього):

$$
S=\sum_{n=1}^{N}\left(\sum_{m=1}^{m_{0}} R_{n m}\right)^{2}-\frac{1}{n}\left(\sum_{n=1}^{N} \sum_{m=1}^{m_{0}} R_{n m}\right)^{2},
$$

де $R_{n m}$ ранг оцінки, наданої $m$-м експертом, по $n$-й альтернативі.

3 врахуванням пріоритетів експертів оцінки будуть мати вигляд:

$$
F_{n m}=f_{n m} W_{\Sigma m}, \quad n=\{1,2, \ldots, N\} .
$$

Для того, щоб проранжувати отримані оцінки, приписуємо кожній значення натурального ряду таким чином, щоб ранг $n$ був приписаний максимальній оцінці, а ранг 1 - мінімальній. В деяких випадках сумарні оцінки рангів нормуються, після чого знов мають бути проранжовані. Тобто здійснюється переведення оцінок в ранги [12]. Коли $E=0$, узгодженості експертів взагалі немає. Якщо $E \leq 0,2 \ldots 0,4$, узгодженість експертів низька. Це може бути наслідком наявності в групі експертів коаліцій $з$ високою узгодженістю думок, однак із зовсім протилежною думкою до інших, або серед експертів відсутня спільність думок. Якщо $E=1-$ узгодженість експертів повна, але це не завжди об'єктивна думка експертів. Може бути ситуація, коли експерти завчасно змовились, захищаючи свої інтереси.

Необхідно, щоб значення $E$ було більш заданого порогового значення $E_{n o p}\left(E>E_{n o p}\right)$. Можливо прийняти $E_{n o p}=0,5$, тобто при $E>0,5$ дії експертів в більшості узгоджені. При $E<0,5$ дії експертів не можна вважати достовірними і слід здійснювати експертизу спочатку. Для отримання достовірних оцінок потребують уточнення вхідні дані, або є потреба в зміні складу групи експертів. Наприклад, отримана оцінка у вигляді ранжування альтернатив, яку проводить експертна група 3 4-х експертів (табл. 10).

\begin{tabular}{|c|c|c|c|c|c|c|c|c|}
\hline \multicolumn{2}{|c|}{ Сценарії } & ІІПВ1 & ІІПВ2 & ІІПВ3 & ІПВ4 & ІПВ5 & IПВ6 & \multirow{6}{*}{ 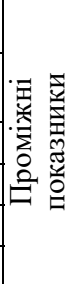 } \\
\hline \multicolumn{2}{|r|}{$W_{\Sigma m}$} & $Y_{1}$ & $Y_{2}$ & $Y_{3}$ & $Y_{4}$ & $Y_{5}$ & $Y_{6}$ & \\
\hline \multirow{4}{*}{ 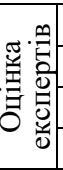 } & \begin{tabular}{|l|l|}
$\mathrm{J} 1$ & 0,255 \\
\end{tabular} & 1 & 2 & 3 & 4 & 5 & 6 & \\
\hline & \begin{tabular}{|l|l|} 
J3 & 0,252 \\
\end{tabular} & 2 & 1 & 4 & 3 & 6 & 5 & \\
\hline & \begin{tabular}{|l|l|}
$\mathrm{J} 2$ & 0,251 \\
\end{tabular} & 2 & 3 & 4 & 6 & 6 & 1 & \\
\hline & \begin{tabular}{|l|l|} 
J4 & 0,243 \\
\end{tabular} & 4 & 3 & 5 & 3 & 6 & 2 & \\
\hline \multirow{3}{*}{ 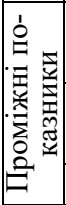 } & $\begin{array}{c}\text { Сума } \\
\text { рангів }\end{array}$ & 9 & 9 & 16 & 16 & 25 & 14 & 89 \\
\hline & \begin{tabular}{|c|} 
Квадрат \\
суми \\
\end{tabular} & 81 & 81 & 256 & 256 & 625 & 196 & 1495 \\
\hline & & & & & & & & \\
\hline \multicolumn{9}{|c|}{$s=174,83 ; e=0,608$} \\
\hline
\end{tabular}

Таблиця 10

Скорегована таблиця розрахунків проміжних показників для розрахунку коефіцієнта конкордації

Отримана оцінка $E=0,608$ говорить про узгодженість думок експертів. 


\section{Висновки}

Таким чином, в статті запропонована комбінована методика визначення компетентності експертів та оцінювання їх узгодженості при виборі сценарію ІПВ. Існують ситуації, коли потрібно прийняти рішення нешаблонного характеру, для чого необхідні не тільки досвід та знання, але й інноваційний, творчий характер роботи експертів. Методика, що пропонується, враховує індивідуальні якості експертів, в тому числі нестандартні, такі як творче мислення, інтелектуальні здібності, талант, особиста ініціатива ОПР, самооцінка та інші. Такий підхід дозволяє за- лучати в експерти групи фахівців, що не мають високих посадових або наукових регалій, але можуть приймати нестандартні рішення, або є вузькокваліфікованими спеціалістами. Також методика дозволяє здійснювати перевибір групи експертів в залежності від сценаріїв ІПВ. При плануванні IПсО може бути задіяно декілька груп експертів, визначених за особливостями впливу на противника. Рішення, отримані за таким підходом, є досить гнучкими та мають високу ступінь адаптивності. Безпосередньо сам процес прийняття рішення в залежності від багатьох критеріїв потребує додаткових досліджень і буде розглядатися в подальшому.

\section{Список літератури}

1. Інформаційно-психологічна боротьба у воєнній сфері: монографія / Г.В. Пєвцов, А.М. Гордієнко, С.В. Залкін, С.О. Сідченко, А.О. Феклістов, К.І. Хударковський. - Х.: Вид. Рожко С.Г., 2017. - 276 с.

2. Снежкова И.А. Отражение гибридной войны в электронных ресурсах Украины и России / И.А. Снежкова // Вестник антропологии. - 2016. - № 4(36). - С. 175-185.

3. Смирнова А.Н. Ограничение воюющих в выборе методов и средств ведения войны / А.Н. Смирнова // Вестник экономической безопасности. - 2017. - № 4. - С. 182-184.

4. Інформаційна війна, соціально-онтологічний та мілітарний аспекти: монографія / Р.В. Гула, О.П. Дзьобань, І.Г. Передерій, О.О. Павліченко, Г.О. Філь. - К.: Каравела, 2020. - 287 с.

5. Ситнова И.В. Информационно-психологическое воздействие как практика ведения войн четвертого поколения / И.В. Ситнова, А.А. Поляков // Власть. - 2018. - № 7. - С. 70-75. https://doi.org/10.31171/vlast.v26i7.5932.

6. Снежкова И.А. Особенности информационной войны Украины против России: способы, приемы и методы [Електронний ресурс] / И.А. Снежкова // Власть. $\quad$ - $2018 . \quad$ - № $3 . \quad$ - С. $125-129$. https://www.jour.isras.ru/index.php/vlast/article/view/5747/5539.

7. Загорка О.М. Багатокритеріальні методи прийняття рішень органами військового управління [Електронний ресурс] / О.М. Загорка, А.К. Павліковський, І.О. Загорка // Сучасні інформаційні технології у сфері безпеки та оборони. 2018. - № 2. - С. 5-12. - Режим доступу: http://nbuv.gov.ua/UJRN/sitsbo_2018_2_2.

8. Архипов А.Е. Оценивание уровня компетентности экспертов по результатам многообъектной экспертизы [Електронний ресурс] / А.Е. Архипов, С.А. Архипова // Економіка та держава. - 2015. - № 6. - С. 29-33. - Режим доступу: http://nbuv.gov.ua/UJRN/ecde_2015_6_8.

9. Петриченко Г.С. Методика оценки компетентности экспертов [Електронний ресурс] / Г.С. Петриченко, В.Г. Петриченко // Научный журнал КубГАУ. - 2015. - № 109(05). - Режим доступу: https://cyberleninka.ru/article/n/metodikaotsenki-kompetentnosti-ekspertov/viewer.

10. Волокобинский М.Ю. Принятие решений на основе метода анализа иерархий [Електронний ресурс] / М.Ю. Волокобинский, О.А. Пекарская, Д.А. Рази // Финансы: теория и практика.- 2016. - № 2(20). - С. 33-42. https://doi.org/10.26794/2587-5671-2016-20-2-33-42.

11. Фандеева Е.А. Применение метода анализа иерархий для выбора рекламной сети в интернете [Електронний ресурс] / Е.А. Фандеева, В.В. Харченко // Радіоелектроніка, інформатика, управління.- 2014. - № 1. - С. 89-95. - Режим доступу: http://nbuv.gov.ua/UJRN/riu_2014_1_15.

12. Афоничкин А.И. Управленческие решения в экономических системах / А.И. Афоничкин, Д.Г. Михаленко. СПб.: Питер Пресс, 2009. - 480 с.

13. Денисова А.Л. Теория и практика экспертной оценки товаров и услуг / А.Л. Денисова, Е.В. Зайцев. - Тамбов: ТГТУ, 2002. $-72 \mathrm{c}$.

14. Мыльник В.В. Исследование систем управления / В.В. Мыльник, Б.П. Титаренко. - М.: Трикста, 2006. - 322 с. $224 \mathrm{c}$.

15. Саати Т. Аналитическое планирование. Организация систем / Т. Саати, К. Керне. - М.: Радио и связь, 1991. -

16. Саати Т.Л. Принятие решений. Метод анализа иерархий. Экономическая теория денег, банковского дела и финансовых рынков / Т.Л. Саати. - М.: Радио и связь, 1993. -278 с.

17. Таха Х.А. Исследование операций / Х.А. Таха. - СПб.: Диалектика, 2018. - 1056 с.

18. Литвак Б.Г. Экспертные оценки и принятие решений / Б.Г. Литвак. - М.: Патент, 1996. - 271 с.

19. Плюта В. Сравнительный многомерный анализ в экономических исследованиях: методы таксономии и факторного анализа / В. Плюта. - М.: Статистика, 1980. - 151 с.

20. Можаровський В.М. Основні положення методики визначення варіанта (способу) бойових дій та складу угруповання військ (сил) для відбиття агресії / В.М. Можаровський, О.М. Загорка // Наука і оборона. - 2011. - № 1. - С. 3-6.

21. Дрешер М. Стратегические игры: теория и приложения: пер. с англ. / М. Дрешер. - М.: Сов. радио, 1964. - 352 с.

22. Ткаченко В.І. Теорія прийняття рішень органами військового управління: монографія / В.І. Ткаченко, С.Б. Смірнов. - Х.: ХУПС, 2008. -545 c. 
23. Туник Е.Е. Лучшие тесты на креативность. Диагностика творческого мышления / Е.Е. Туник. - СПб.: Питер, 2013. $-320 \mathrm{c}$.

24. Ленкова А.А. Дивергентное мышление как предмет психолого-педагогического исследования [Електронний ресурс] / А.А. Ленкова // Сибирский педагогический журнал.- 2009. - № 10. - С. 250-255. - Режим доступу: https://cyberleninka.ru/article/n/divergentnoe-myshlenie-kak-predmet-psihologo-pedagogicheskogo-issledovaniya.

25. Мироненко Л.А. Эмпирическая социология / Л.А. Мироненко. - Комсомольск на Амуре: КнАГТУ, 2013. $181 \mathrm{c}$.

26. Харькова О.А. Статистические методы и математическое моделирование / О.А. Харькова, А.Г. Соловьев. Архангельск: СГМУ, 2017. - 164 с.

\section{References}

1. Pievtsov, H.V., Hordiienko, A.M., Zalkin, S.V., Sidchenko, S.O., Feklistov, A.O. and Khudarkovskyi, K.I. (2017), "Informatsiino-psykholohichna borotba u voiennii sferi" [Information-psychological struggle in the military sphere], Rozhko S.H., Kharkiv, 276 p.

2. Snezhkova, Y.A. (2016), "Otrazhenye hybrydnoi voiny v elektronnykh resursakh Ukrayny y Rossyy” [Reflection of hybrid war in electronic resources of Ukraine and Russia], Bulletin of Anthropology, No. 4(36), pp. 175-185.

3. Smyrnova, A.N. (2017), "Ohranychenye voiuiushchykh v vybore metodov y sredstv vedenyia voiny" [Restriction of warriors in the choice of methods and means of warfare], Bulletin of Economic Security, No. 4, pp. 182-184.

4. Hula, R.V., Dzoban, O.P., Perederii, I.H., Pavlichenko, O.O. and Fil, H.O. (2020), "Informatsiina viina, sotsialnoontolohichnyi ta militarnyi aspekty" [Information warfare, socio-ontological and militaristic aspects], Karavela, Kyiv, 287 p.

5. Sytnova, Y.V. and Poliakov, A.A. (2018), "Ynformatsyonno-psykholohycheskoe vozdeistvye kak praktyka vedenyia voin chetvertoho pokolenyia" [Information and psychological impact as a practice of waging fourth-generation wars], Power, No. 7, pp. 70-75. https://doi.org/10.31171/vlast.v26i7.5932.

6. Snezhkova, Y.A. (2018), "Osobennosty ynformatsyonnoi voiny Ukrayny protyv Rossyy: sposoby, pryemy y metody" [Features of the information war of Ukraine against Russia: methods, techniques and methods], Power, No. 3, pp. 125-129, available at: https://www.jour.isras.ru/index.php/vlast/article/view/5747/5539.

7. Zahorka, O.M., Pavlikovskyi, A.K. and Zahorka, I.O. (2018), "Bahatokryterialni metody pryiniattia rishen orhanamy viiskovoho upravlinnia" [Multicriteria decision-making methods by military authorities], Modern Information Technologies in the Field of Security and Defense, No. 2, pp. 5-12, available at: https://nbuv.gov.ua/UJRN/sitsbo_2018_2_2.

8. Arkhypov, A.E. and Arkhypova, S.A. (2015), “Otsenyvanye urovnia kompetentnosty ekspertov po rezultatam mnohoobyektnoi ekspertyzy" [Assessment of the level of competence of experts on the results of multi-objective examination], Economy and the State, No. 6, pp. 29-33, available at: http://nbuv.gov.ua/UJRN/ecde_2015_6_8.

9. Petrychenko, H.S. and Petrychenko, V.H. (2015), "Metodyka otsenky kompetentnosty ekspertov" [Expertise assessment methodology], Scientific Journal of the Kuban State Agrarian University, No. 109(05), available at: https://cyberleninka.ru/article/n/metodika-otsenki-kompetentnosti-ekspertov/viewer.

10. Volokobynskyi, M.Yu., Pekarskaia, O.A. and Razy, D.A. (2016), "Pryniatye reshenyi na osnove metoda analyza yerarkhyi" [Decision making based on hierarchy analysis], Finance: Theory and Practice, No. 2(20), pp. 33-42. https://doi.org/10.26794/2587-5671-2016-20-2-33-42.

11. Fandeeva, Ye.A. and Kharchenko, V.V. (2014), "Prymenenye metoda analyza yerarkhyi dlya vybora reklamnoi sety v ynternete" [Application of hierarchy analysis method for choosing an advertising network on the Internet], Radio Electronics, Informatics, Control, No. 1, pp. 89-95, available at: http://nbuv.gov.ua/UJRN/riu_2014_1_15.

12. Afonychkyn, A.I. and Mykhalenko, D.H. (2009), "Upravlencheskye reshenyia v ekonomycheskykh systemakh" [Management decisions in economic systems], Pyter Press, Saint Petersburg, 480 p.

13. Denysova, A.L. and Zaitsev, Ye.V. (2002), "Teoryia y praktyka ekspertnoi otsenky tovarov y usluh" [Theory and practice of expert evaluation of goods and services], THTU, Tambov, $72 \mathrm{p}$.

14. Mylnyk, V.V. and Tytarenko, B.P. (2006), "Yssledovanye system upravlenyia" [Management Systems Research], Tryksta, Moscow, $322 \mathrm{p}$.

15. Saaty, T. and Kerne, K. (1991), "Analytycheskoe planyrovanye. Orhanyzatsyia system” [Analytical planning. System organization], Radio i Svyaz, Moscow, 224 p.

16. Saaty, T.L. (1993), "Pryniatye reshenyi. Metod analyza yerarkhyi. Ekonomycheskaia teoryia deneh, bankovskoho dela y fynansovykh rynkov" [Making decisions. Hierarchy Analysis Method. The economic theory of money, banking and financial markets], Radio i Svyaz, Moscow, 278 p.

17. Takha, Kh.A. (2018), "Yssledovanye operatsyi” [Operations research], Dyalektyka, Saint Petersburg, 1056 p.

18. Lytvak, B.G. (1996), "Ekspertnye otsenky y pryniatye reshenyi” [Expertise and decision making], Patent, Moscow, $271 \mathrm{p}$.

19. Pliuta, V. (1980), "Sravnytelnyi mnohomernyi analyz $v$ ekonomycheskykh yssledovanyiakh: metody taksonomyy y faktornoho analyza" [Comparative multivariate analysis in economic research: taxonomy and factor analysis methods], Statystyka, Moscow, $151 \mathrm{p}$.

20. Mozharovskyi, V.M. and Zahorka, O.M. (2011), “Osnovni polozhennia metodyky vyznachennia varianta (sposobu) boiovykh dii ta skladu uhrupovannia viisk (syl) dlia vidbyttia ahresii" [The main provisions of the method of determining the variant (method) of combat operations and the composition of troops (forces) for repelling aggression], Science and Defense, No. 1, pp. 3-6. 
21. Dresher, M. (1964), "Stratehycheskye igri: teoryia y prylozhenyia" [Strategy games: theory and applications], Sovetskoe radyo, Moscow, $352 \mathrm{p}$.

22. Tkachenko, V.I. and Smirnov, Ye.B. (2008), "Teoriya pryiniattia rishen orhanamy viiskovoho upravlinnia" [The theory of decision making by the military authorities], KhUPS, Kharkiv, $545 \mathrm{p}$.

23. Tunyk, Ye.Ye. (2013), "Luchshye testy na kreatyvnost. Dyahnostyka tvorcheskoho myshlenyia" [The best tests for creativity. Diagnosis of creative thinking], Piter, Saint Petersburg, 320 p.

24. Lenkova, A.A. (2009), "Dyverhentnoe myshlenye kak predmet psykholoho-pedahohycheskoho yssledovanyia" [Divergent thinking as a subject of psychological and pedagogical research], Siberian Pedagogical Journal, No. 10, pp. 250-255, available at: https://cyberleninka.ru/article/n/divergentnoe-myshlenie-kak-predmet-psihologo-pedagogicheskogo-issledovaniya.

25. Myronenko, L.A. (2013), "Empyrycheskaia sotsyolohyia” [Empirical sociology], KnAHTU, Komsomolsk na Amure, $181 \mathrm{p}$.

26. Kharkova, O.A. and Solovev, A.G. (2017), "Statystycheskye metody i matematycheskoe modelyrovanye" [Statistical methods and mathematical modeling], SHMU, Arkhanhelsk, 164 p.

Надійшла до редколегії 14.02.2020

Схвалена до друку 17.03.2020

\section{Відомості про авторів:}

\section{Псвцов Геннадій Володимирович} доктор технічних наук професор заступник начальника Харківського національного університету Повітряних Сил ім. І. Кожедуба з наукової роботи,

Харків, Україна

https://orcid.org/0000-0002-0426-6768

\section{Усачова Ольга Анатоліївна}

кандидат технічних наук старший науковий співробітник начальник науково-дослідного відділу

Харківського національного університету

Повітряних Сил ім. І. Кожедуба,

Харків, Україна

https://orcid.org/0000-0003-0864-5017

\section{Пацек Петро}

доктор філософії викладач

Академії військового мистецтва,

Варшава, Польща,

https://orcid.org/0000-0002-2182-2316

\section{Романюк Алла Олександрівна}

науковий співробітник

Харківського національного університету

Повітряних Сил ім. І. Кожедуба,

Харків, Україна

https://orcid.org/0000-0001-5882-6962

\section{Information about the authors:}

Hennadii Pievtsov

Doctor of Technical Sciences Professor

Deputy Head of Ivan Kozhedub

Kharkiv National Air Force University

in Science,

Kharkiv, Ukraine

https://orcid.org/0000-0002-0426-6768

Olga Usacheva

Candidate of Technical Sciences Senior Research

Chief of Scientific Research Department

of Ivan Kozhedub Kharkiv

National Air Force University,

Kharkiv, Ukraine

https://orcid.org/0000-0003-0864-5017

Piotr Pacek

Doctor of Philosophy Lecturer

of The War Studies University,

Warsaw, Poland

https://orcid.org/0000-0002-2182-2316

Alla Romaniuk

Research Associate

of Ivan Kozhedub Kharkiv

National Air Force University,

Kharkiv, Ukraine

https://orcid.org/0000-0001-5882-6962

\title{
КОМБИНИРОВАННАЯ МЕТОДИКА ОЦЕНИВАНИЯ КОМПЕТЕНТНОСТИ ЭКСПЕРТОВ ПРИ ВЫБОРЕ СЦЕНАРИЯ ОРГАНИЗАЦИИ ИНФОРМАЦИОННО-ПСИХОЛОГИЧЕСКОГО ВЛИЯНИЯ
}

\author{
Г.В. Певцов, О.А. Усачова, П. Пацек, А.А. Романюк
}

Предложена методика оценки компетентности экспертов при выборе рационального сценария принятия решения на организацию информаиионно-психологического воздействия (ИПВ). Представлена в общем виде модель выбора сценария принятия решения на организачию ИПВ, которая включает в себя элементы различных методов, в том числе метода анализа иерархий. Оптимизация группового решения осуществляется на основе обоснованной процедуры согласования. Особенностью модели является то, что она учитывает показатель приоритета эксперта в группе, который характеризует его компетентность (важность) в области информационно-психологической борьбы. Кроме того, для оценки компетентности экспертов, осуществляющих выбор сценария, учтены нестандартные характеристики, такие как творческое мышление, многовариантность решений, гибкость, способность к абстрактному мылилению, креативность. Введение показателя компетентности эксперта позволяет существенно упростить методику обработки данных групповой экспертизы и сделать результаты ее применения более достоверными. Также предложен алгоритм расчета минимальной численности экспертов для проведения экспертизы объектов воздействия.

Ключевые слова: групповая экспертиза, информачионно-психологическое воздействие, компетентность, принятие решения, творческое мышление. 


\title{
COMBINED METHOD FOR ASSESSING THE COMPETENCE OF EXPERTS WHEN CHOOSING SCENARIO OF ORGANIZING INFORMATION AND PSYCHOLOGICAL INFLUENCE
}

\author{
H. Pievtsov, O. Usacheva, P. Pacek A. Romaniuk
}

The article proposes combined methodology for determining the competence of experts and assessing their consistency when choosing a scenario of information and psychological influence. The problem of selecting experts for conducting an examination and determining the best scenario of information and psychological influence is one of the most difficult expert studies in theory and practice. The insufficient level of expert competence leads to the appearance of many errors and subsequently to large economic, political, and military losses. The methodology proposed in the article takes into account the individual qualities of experts, including non-standard ones, such as creative thinking, intellectual abilities, talent, personal initiative of commanders, self-esteem and others. The generally presented model for choosing scenario for deciding on the organization of information and psychological influence includes elements of various methods, including the hierarchy analysis method. Optimization of group decisions is carried out on the basis of reasonable approval process. The feature of the model is that it takes into account the priority indicator of the expert in the group, which characterizes his competence (importance) in the field of information and psychological operations. In addition, to assess the competence of the experts who choose the scenario, non-standard characteristics, such as creative thinking, multivariance of decisions, flexibility, ability to abstract thinking, creativity, were taken into account. The introduction of an expert's competency index allows to significantly simplify the methodology for processing group examination data and make the results of its application more reliable. An algorithm for calculating the minimum number of experts for the examination of impact objects is also proposed. According to the results of the research, it is clear that if the priority is given to the criteria that are responsible for the non-standard solution, then the group will include not only experts with high level of education, but also young specialists with high rates of unconventional thinking. Such approach allows attracting groups of experts into the experts who do not have high official or scientific regalia, but can make non-standard decisions, or are highly qualified specialists. In addition, this methodology allows for re-election of experts depending on the scenarios of information and psychological influence.

Keywords: group examination, information and psychological influence, competence, decision, creative thinking. 